\title{
Review \\ Recent development of TiNi-based shape memory alloys in Taiwan *
}

\author{
S.K. Wu ${ }^{\mathrm{a}, *}$, H.C. Lin $^{\mathrm{b}}$ \\ ${ }^{a}$ Institute of Materials Science and Engineering, National Taiwan University, Taipei, Taiwan 106, China \\ b Department of Materials Science, Feng Chia University, Taichung, Taiwan 407, China \\ Received 23 March 1999; received in revised form 16 July 1999; accepted 20 July 1999
}

\begin{abstract}
TiNi-based alloys are considered to be the most important shape memory alloys (SMAs) because of their salient shape memory effect (SME), pseudoelasticity (PE) and high damping capacity (HDC). Recent investigations focus on their transformation behaviors, thermal-mechanical treatments, manufacturing processes, and industrial applications based on the characteristics of SME, PE and HDC. The two-stage martensitic transformations of B2 $\leftrightarrow$ R-phase $\leftrightarrow$ B19' and B2 $\leftrightarrow$ B19 $\leftrightarrow$ B19' have been clarified for both TiNi binary and ternary alloys. The deformation behaviors have been investigated by cold-rolling, hot-rolling and wire drawing. Both SME and PE can be improved by thermal-mechanical treatments, and the damping characteristics of TiNi and TiNiX SMAs have been systematically studied. Both B19'/B19 martensite and R-phase have high damping capacities due to the easy stress-induced movement of twin boundaries. The high temperature SMAs, Ti-Ni-X with $\mathrm{X}=\mathrm{Au}, \mathrm{Pd}$ and $\mathrm{Zr}$ alloys, have also been intensively studied. The ion nitriding technique has been used to improve the wear and corrosion resistance of TiNi and TiNiX SMAs. TiNi thin films have been successfully fabricated using the sputter-deposition technique. These investigations on the TiNi-based SMAs have attracted much attention and their important characteristics will be applied widely in the near future. (C2000 Elsevier Science S.A. All rights reserved.
\end{abstract}

Keywords: TiNi SMAs in Taiwan; Shape memory effect; Pseudoelasticity; Damping capacity; Deformation behavior; TiNi thin films

\section{Introduction}

Shape memory materials have attracted considerable attention in recent years as functional materials in a variety of industrial and medical applications. They have also been identified as important smart materials because of their ability to perform both sensing and actuating functions [1]. Among the practical shape memory materials, TiNi-based alloys are the most commonly used because of their excellent mechanical properties, corrosion resistance and biocompatibility.

TiNi shape memory alloys (SMAs) are known for their shape memory effect (SME) [2] and pseudoelasticity (PE) $[3,4]$. A great number of investigations have been conducted on SME/PE, currently understood as a phenomenon essentially associated with the thermoelastic martensitic transformation. The transformation behaviors and mechan-

\footnotetext{
is This paper was presented at the 1998 APAM Seminar.

* Corresponding author. Tel.: +886-02-2363-7846; fax: +886-02-2363-4562.

E-mail address: skw@ccms.ntu.edu.tw (S.K. Wu).
}

ical properties in TiNi alloys can be affected by various thermo-mechanical treatments such as cold working [5-9], thermal cycling [10,11], aging of Ni-rich alloys [12-17] and the addition of a ternary element [18-31]. In addition to SME/PE properties, TiNi alloys can exhibit a high mechanical damping capacity due to the easy movement of twin boundaries [32,33], and an excellent wear/erosion resistance resulting from their rapid work hardening and PE properties [34-37]. Most shape memory alloys can not be used at temperatures above $100^{\circ} \mathrm{C}$, due to the limitation of available martensitic transformation temperatures. To extend their industrial applications, SMAs which can exhibit high temperature SME are in high demand. Ti-Ni-X $(X=\mathrm{Au}$, $\mathrm{Pd}$ and $\mathrm{Zr}$ ) ternary alloys have been developed as potential high temperature SMAs [23-26]. To create new applications and enhance the performance of TiNi-based alloys, several investigations on surface modification have been performed to improve their surface properties [38-42]. The recent development of micro-machines or micro-actuators has been a priority in fields such as medicine, biochemistry and semiconductors. Among the several types of high performance materials, TiNi thin films are excellent 
candidates in fabricating micro-actuators. Hence, efforts have been made to fabricate TiNi thin films using many different coating techniques [43-59].

\section{Transformation behaviors}

\subsection{B2 $\leftrightarrow R$-phase $\leftrightarrow B 19^{\prime}$ martensite}

It is well known that the R-phase transformation can appear prior to the martensitic transformation after some treatments, such as the addition of a ternary element $[18,27,60]$, low temperature annealing treatments following cold work [5,6], thermal cycling [10,11,61-64] and aging of Ni-rich alloys [12-17]. Fig. 1 shows that the $\mathrm{Ti}_{49} \mathrm{Ni}_{51}$ alloy aged at $400^{\circ} \mathrm{C}$ can exhibit the transformation sequence of $\mathrm{B} 2 \leftrightarrow \mathrm{R}$-phase $\leftrightarrow \mathrm{B} 19^{\prime}$ martensite. In the early aging stage (Fig. 1b), only the R-phase transformation is observed due to the Ms point being deeply depressed by the coherent stress of $\mathrm{Ti}_{11} \mathrm{Ni}_{14}$ precipitates [17,65-69]. In the later aging stage (Fig. 1c), the R-phase and martensitic transformations are all observed on both heating and cooling cycles.

In order to understand the variation of $T_{\mathrm{R}}, T_{\mathrm{R}}^{*}$ (DSC peak temperatures associated with the R-phase transformation) and $\Delta H$ value with the aging time, and the relationship between $\Delta H$ and $T_{\mathrm{R}}\left(T_{\mathrm{R}}^{*}\right), \mathrm{Ti}_{49} \mathrm{Ni}_{51}$ specimens are aged at $300^{\circ} \mathrm{C}$ for various periods of time and measured by DSC. In Fig. 2a, all $T_{\mathrm{R}}, T_{\mathrm{R}}^{*}$ and $\Delta H$ values increase quickly in early aging and then approach steady values. At the same time, in Fig. 2a, the variation of $\Delta H$ values with the aging time has

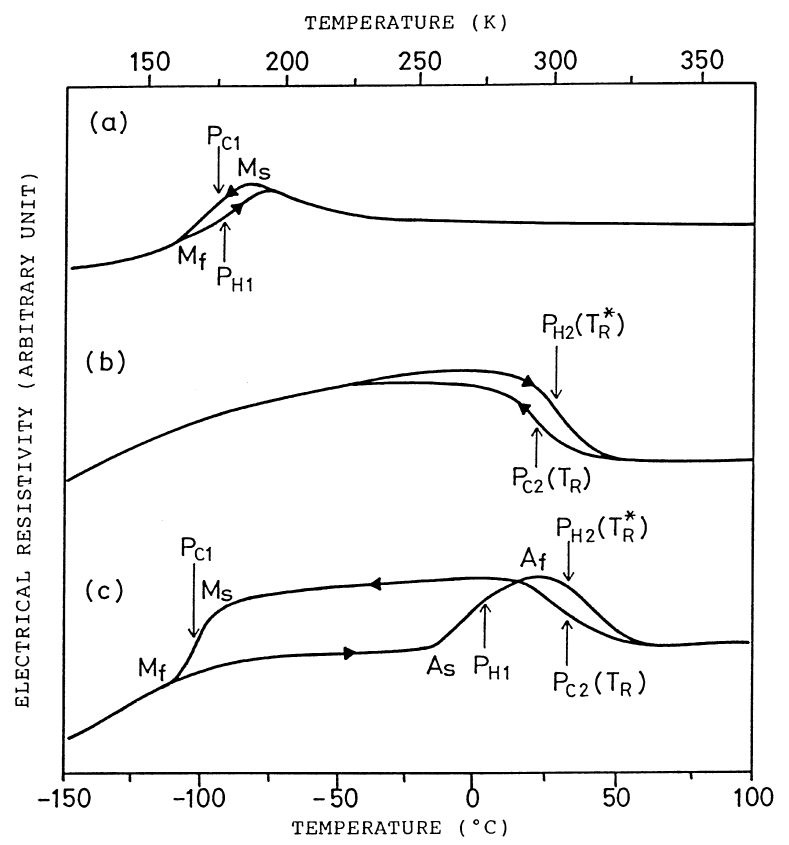

Fig. 1. Electrical resistivity vs. temperature curves for (a) $800^{\circ} \mathrm{C} \times 2 \mathrm{~h}$ annealed and water quenched (solution treated) $\mathrm{Ti}_{49} \mathrm{Ni}_{51}$ alloy. (b) The same as (a), but now followed by the $400^{\circ} \mathrm{C} \times \mathrm{h}$ aging. (c) The same as (a), but now followed by the $400^{\circ} \mathrm{C} \times \mathrm{h}$ aging.
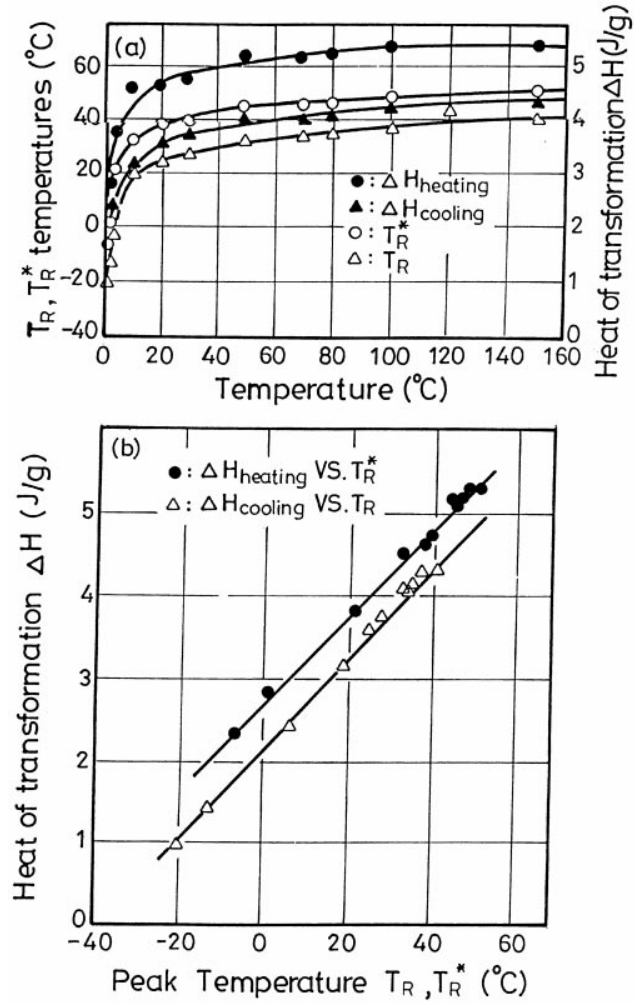

Fig. 2. (a) $T_{\mathrm{R}}, T_{\mathrm{R}}^{*}$ and $\Delta H$ as a function of aging time. (b) $\Delta \mathrm{H}$ as a function of transformation peak temperatures $T_{\mathrm{R}}$ and $T_{\mathrm{R}}^{*}$.

the same tendency as that of $T_{\mathrm{R}}$ and $T_{\mathrm{R}}^{*}$. Hence, a linear relationship between $\Delta H$ and $T_{\mathrm{R}}\left(T_{\mathrm{R}}^{*}\right)$ is found in Fig. 2b. From a thermodynamic viewpoint, $\Delta H$ value is expected to be linearly related to the transformation temperature under the assumption that the martensitic transformation is 'thermoelastic' in nature [70,71]. Hence, the results of Fig. 2b imply that the R-phase transformation has the characteristic of a 'thermoelastic' transformation. The crystal structure of R-phase has been identified, mainly by using electron diffraction [72,73] and X-ray diffraction [18], as the rhombohedral R-phase with space group P31m. The hexagonal unit cell of the R-phase has dimensions $a_{\mathrm{R}}=7.38 \AA$ and $c_{\mathrm{R}}=5.32 \AA$. The orientation relationship between the $\mathrm{B} 2$ and R-phase is $\left(\begin{array}{lll}1 & 11\end{array}\right)_{\mathrm{B} 2} / /\left(\begin{array}{llll}0 & 0 & 1\end{array}\right)_{\mathrm{R}}$ and $\langle 211\rangle_{\mathrm{B} 2} / /\langle 2110\rangle_{\mathrm{R}}$. The R-phase can be formed by elongating any of the four $\left\langle\begin{array}{lll}1 & 1 & 1\end{array}\right\rangle$ directions of the B2 phase, as shown in Fig. 3a with $\langle 111\rangle$ as the elongation direction. After the R-phase is formed, the rhombohedral angle $\alpha$ shown in Fig. 3b will be somewhat $<90^{\circ}$. X-ray diffraction studies indicate that the $\alpha$ will decrease with decreasing temperature, as shown in Fig. 4 and [74,75]. Consequently, the rhombohedral distortion of the R-phase will increase with decreasing temperature. From Fig. 4, one can find that the $\alpha$ values are in fact very close to $90^{\circ}$. Therefore, for the sake of convenience, the B2 cubic index is used to analyze the R-phase, instead of the hexagonal index. Fig. $3 \mathrm{~b}$ shows the example using a cubic index for the R-phase [76]. 


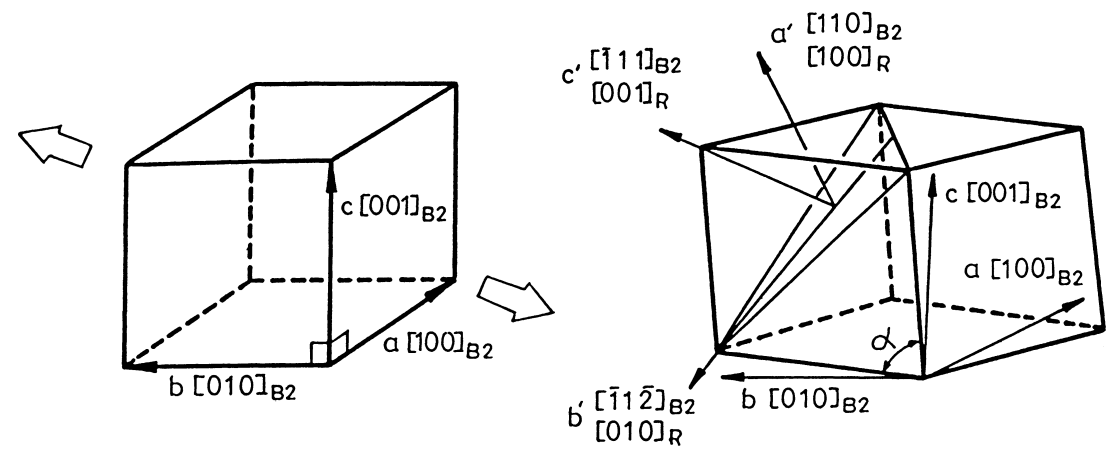

(a)

(b)

Fig. 3. Unit cell of (a) the parent B2 phase, and (b) the R-phase. The principle axes in the lattice deformation associated with the R-phase transformation is also shown in (b).

\section{2. $B 2 \leftrightarrow B 19 \leftrightarrow B 19^{\prime}$ martensite}

The $\mathrm{Ti}_{50} \mathrm{Ni}_{40} \mathrm{Cu}_{10}$ alloy is reported to undergo a typical B2 $\leftrightarrow$ B19 and B19 $\leftrightarrow \mathrm{B} 19^{\prime}$ two-stage martensitic transformation, where B2, B19 and B19' represent cubic, orthorhombic and monoclinic structures, respectively. Fig. 5 shows the results of DSC measurements in both forward and reverse transformations for $\mathrm{Ti}_{50} \mathrm{Ni}_{40} \mathrm{Cu}_{10}$ alloy. In Fig. 5, one can observe two DSC peaks, which appear on each heating/cooling curve. The first transformation appearing at the higher temperature is accompanied with a significant heat effect, whereas the second one appearing at the lower temperature causes only a minor heat effect. These results contrast with those of the electrical resistivity test (Fig. 6) and internal friction measurement [19], where small peaks in the cooling and heating curves are due to the $\mathrm{B} 2 \leftrightarrow \mathrm{B} 19$ martensitic transformation and sharp peaks are associated with the $\mathrm{B} 19 \leftrightarrow \mathrm{B} 19^{\prime}$ martensitic transformation. Fig. 7 shows the $\mathrm{X}$-ray diffraction profiles a-t of $\mathrm{Ti}_{50} \mathrm{Ni}_{40} \mathrm{Cu}_{10}$ alloy, which are obtained at selected temperatures during successive cooling $(\mathrm{a}-\mathrm{j})$ and heating $(\mathrm{k}-\mathrm{t})$ sequences. As shown in Fig. 7, we suggest that the formation of $\mathrm{B} 19^{\prime}$ martensite is characterized by a monoclinic distortion of B19 martensite with respect to the obliqued $b$-axis. The monoclinic angle of $\mathrm{B} 19^{\prime}$ martensite increases with decreasing temperature from $95.8^{\circ}$

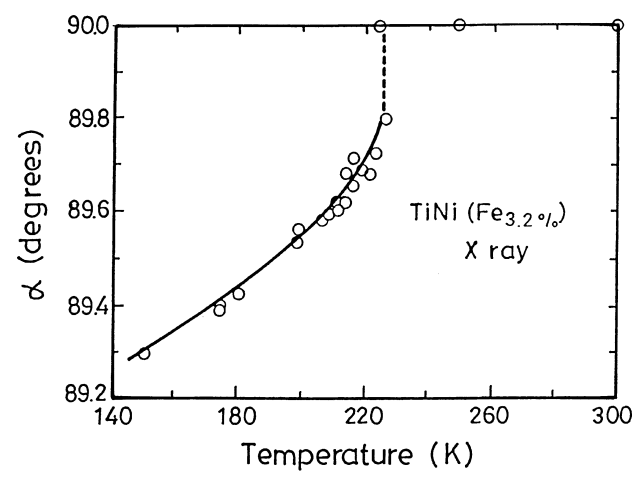

Fig. 4. Rhombohedral angle $\alpha$ determined from X-ray $(2,2,2)_{\mathrm{R}}$ reflections. at $260 \mathrm{~K}$ to $97.2^{\circ}$ at $20 \mathrm{~K}$. The characteristic of the continuously monoclinic distortion of $\mathrm{B} 19^{\prime}$ martensite is rather similar to that of a continuously rhombohedral distortion of R-phase, as mentioned in Section 2.1 [74,75].

The internal friction measurement [19] of $\mathrm{Ti}_{50} \mathrm{Ni}_{40} \mathrm{Cu}_{10}$ alloy indicates that the shear modulus of B19 martensite has an unusually low value over a broad temperature range between the two shear modulus minima of $\mathrm{B} 2 \leftrightarrow \mathrm{B} 19$ and $\mathrm{B} 19 \leftrightarrow \mathrm{B} 19^{\prime}$, i.e. over the temperature range of the B19 martensite. The $\mathrm{B} 2 \leftrightarrow \mathrm{B} 19$ transformation is thus proposed to proceed under the condition of deep shear modulus softening.

\section{Deformation behaviors}

\subsection{Cold-rolling}

Fig. 8 shows plots of internal friction $Q^{-1}$ versus temperature for the $20 \%$ cold-rolled $\mathrm{Ti}_{50} \mathrm{Ni}_{50}$ alloy, and here peaks $P_{\mathrm{H} 1-1}, P_{\mathrm{C} 1}$ and $P_{\mathrm{H} 1-2}$ are all associated with the martensitic transformations. Similar results are obtained for other degrees of cold-rolling. All peak temperatures of $P_{\mathrm{H} 1-1}, P_{\mathrm{C} 1}$ and $P_{\mathrm{H} 1-2}$ at various degrees of cold-rolling (thickness reduction) are plotted in Fig. 9. In Fig. 9, $P_{\mathrm{H} 1-1}, P_{\mathrm{C} 1}$ and $P_{\mathrm{H} 1-2}$ are strongly affected by cold-rolling. The temperature of $P_{\mathrm{H} 1-1}$ significantly increases, but on the contrary, $P_{\mathrm{C} 1}$ and $P_{\mathrm{H} 1-2}$ monotonously decrease, with the increasing degree of cold-rolling. The temperature increment of $P_{\mathrm{H} 1-1}$ can reach $120^{\circ} \mathrm{C}$ for the $40 \%$ thickness-reduced specimen. Comparing the temperature of $P_{\mathrm{H} 1-1}$ to that of $P_{\mathrm{H} 1-2}$, the temperature increment due to the cold-rolling can be substantially annealed out. This result exhibits the phenomena of martensite stabilization, namely, the normally reversed transformation can be prevented and the martensite phase can be 'stabilized' by cold rolling. Thus, the reverse transformation temperatures, As and Af, shift to higher ones. Both deformed martensite structures and deformation-induced dislocations/vacancies 


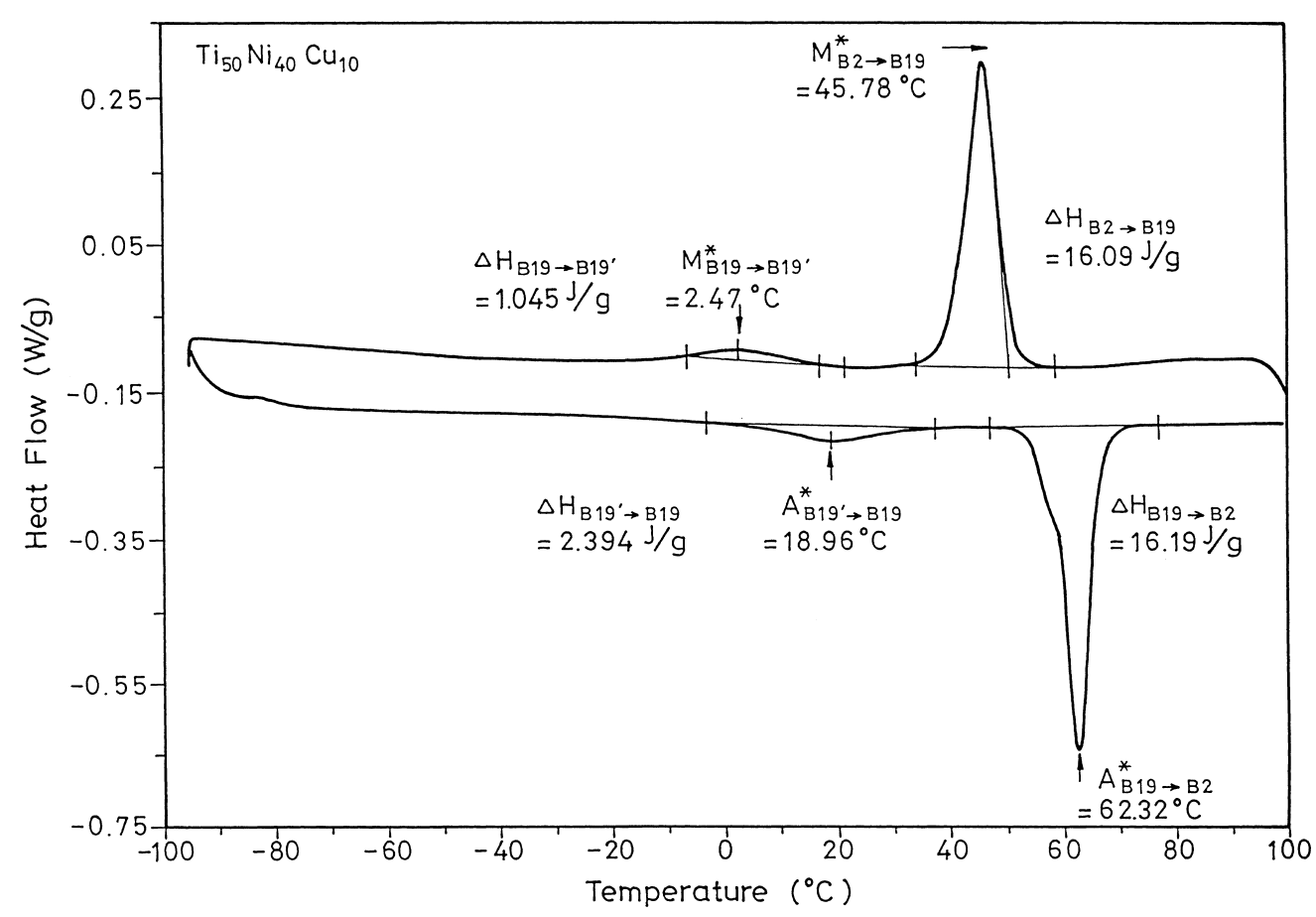

Fig. 5. DSC curves for $\mathrm{Ti}_{50} \mathrm{Ni}_{40} \mathrm{Cu}_{10}$ alloy.

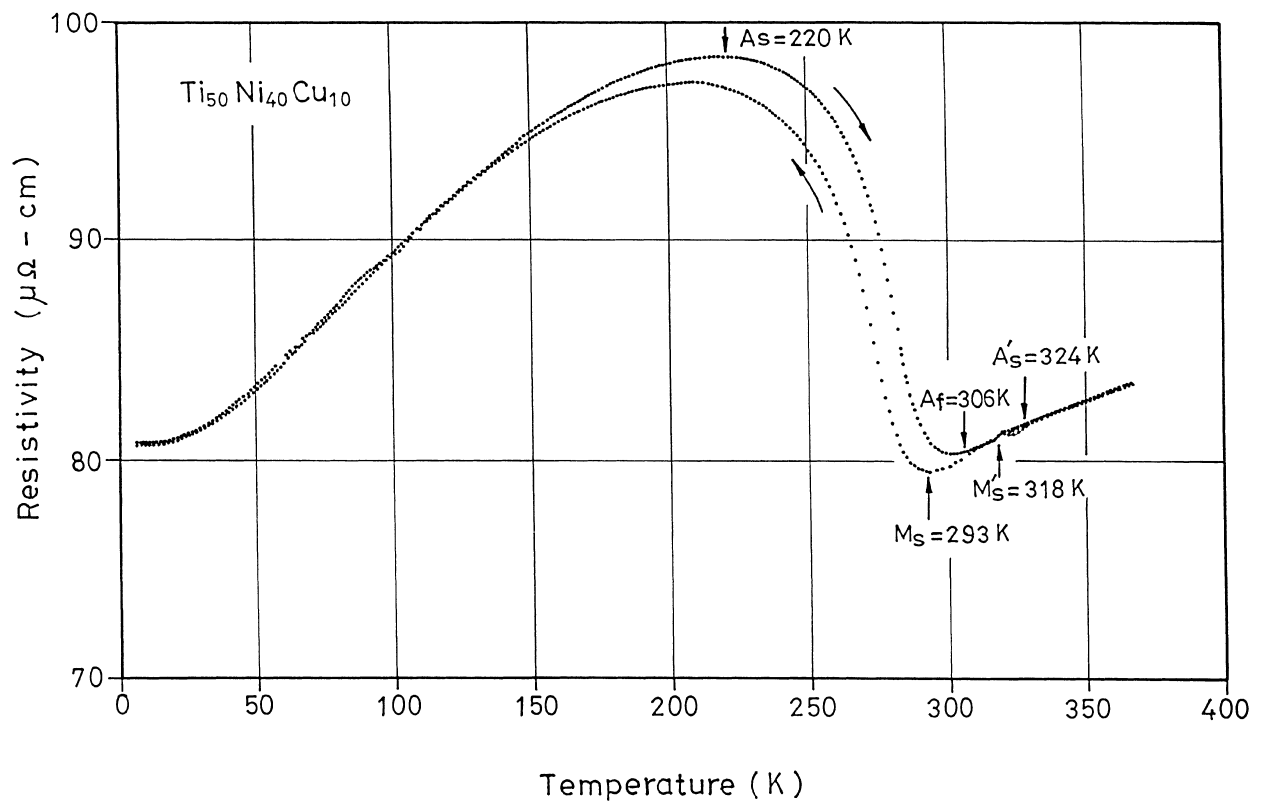

Fig. 6. Electrical resistivity vs. temperature curve of $\mathrm{Ti}_{50} \mathrm{Ni}_{40} \mathrm{Cu}_{10}$ alloy.

are considered to be related to the martensite stabilization. After the occurrence of the first reverse martensitic transformation of $\mathrm{B} 19^{\prime} \leftrightarrow \mathrm{B} 2$, the martensite stabilization dies out and the transformation temperatures are depressed by retained dislocations in subsequent thermal cycles.

The tensile test shows that the martensite accommodation/reorientation process in the as cold-rolled $\mathrm{Ti}_{50} \mathrm{Ni}_{50}$ alloy is depressed due to the hindrance of deformed martensite structures and defects, as indicated in Fig. 10. If the cold-rolled equiatomic $\mathrm{Ti}_{50} \mathrm{Ni}_{50}$ alloy is subjected to a reverse martensitic transformation (RMT) at temperature $<300^{\circ} \mathrm{C}$, the strengthening effect induced by cold-rolling can significantly improve the alloy's SME and PE by raising the critical shear stress for slip. These effects can be summarized in the schematic diagram of Fig. 11. In Fig. 11, $\sigma_{\mathrm{A}}$ and $\sigma_{\mathrm{B}}$ are the critical resolved shear stresses for slip deformation in the alloy with and without a strengthening effect, respectively. If the applied stress exceeds the critical stress 

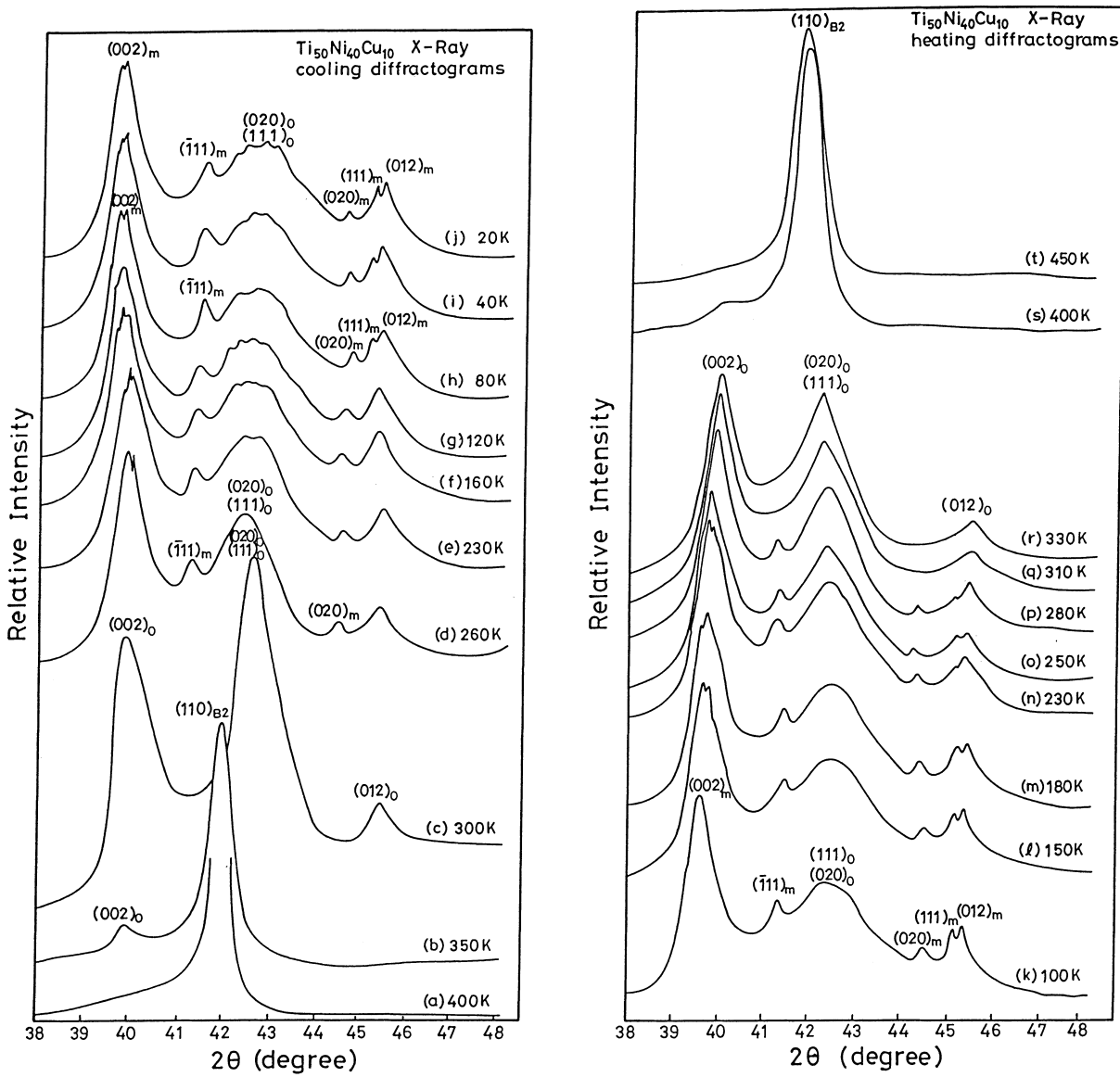

Fig. 7. X-ray diffraction profiles of $\mathrm{Ti}_{50} \mathrm{Ni}_{40} \mathrm{Cu}_{10}$ alloy, which were obtained by successively cooling (a-j) and heating (k-t) the specimen. Subscripts ' $\mathrm{c}$ ', 'o' and ' $\mathrm{m}$ ' of the diffraction peaks represent their origin from the B2, B19 and B19' phases, respectively.

for slip deformation (i.e. $\sigma_{\text {apply }}>\sigma_{\mathrm{B}}$ ), residual strain is introduced and both SME and PE are suppressed. However, if the critical slip stress of TiNi alloy is raised by cold-rolling strengthening (e.g. $\sigma_{\mathrm{A}}>\sigma_{\mathrm{B}}$ in Fig. 11), the permanent strain will be reduced and both SME and PE are improved. At the same time, Ms and Af temperatures are depressed to $\mathrm{Ms}^{\prime}$ and $\mathrm{Af}^{\prime}$ after the cold-rolling [77]. Hence, the oblique line exhibiting the critical stress for stress induced martensite (SIM) is shifted to the lower temperature side, as shown by

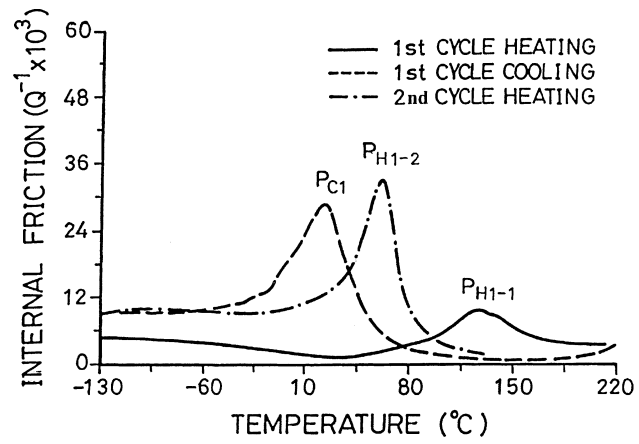

Fig. 8. Internal friction vs. temperature curves for the $20 \%$ thickness-reduced $\mathrm{Ti}_{50} \mathrm{Ni}_{50}$ alloy with specimen thickness $1.04 \mathrm{~mm}$. Peaks $P_{\mathrm{H} 1-1}, P_{\mathrm{C} 1}$ and $P_{\mathrm{H} 1-2}$ are all associated with the martensitic transformation. the dashed oblique line in Fig. 11. Additionally, the vertical line separating the regions of PE and SME is also shifted to the lower temperature side, as shown by the dashed vertical line in Fig. 11. This feature extends the PE applications to the lower temperature range and increases the minimum stress for inducing SIM, as indicated by marks 1 and 2 . Meanwhile, as shown in Fig. 12 for the PE characteristic,

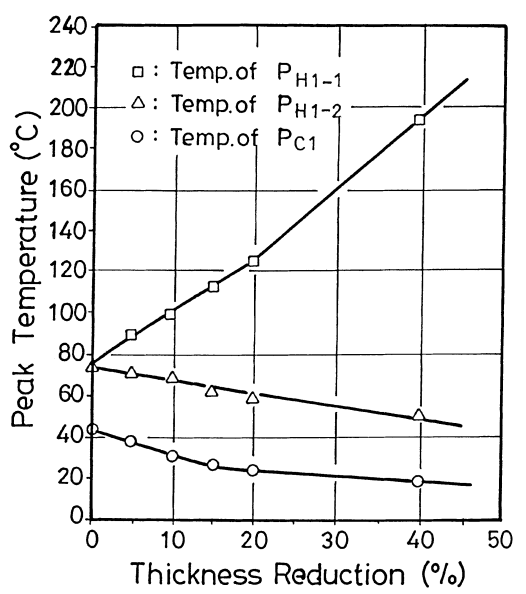

Fig. 9. Peak temperature of $P_{\mathrm{H} 1-1}, P_{\mathrm{C} 1}$ nad $P_{\mathrm{H} 1-2}$ vs. thickness reduction for the $\mathrm{Ti}_{50} \mathrm{Ni}_{50}$ alloy cold-rolled at room temperature. 


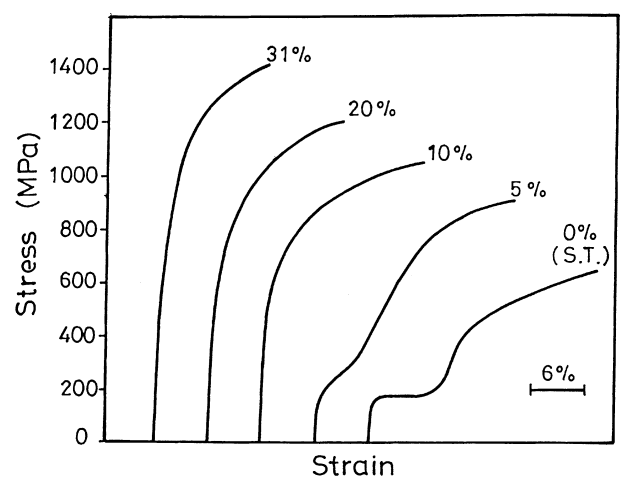

Fig. 10. Typical engineering stress vs. strain curves for solution-treated (S.T.) and S.T.+cold-rolled $\mathrm{Ti}_{50} \mathrm{Ni}_{50}$ specimens.

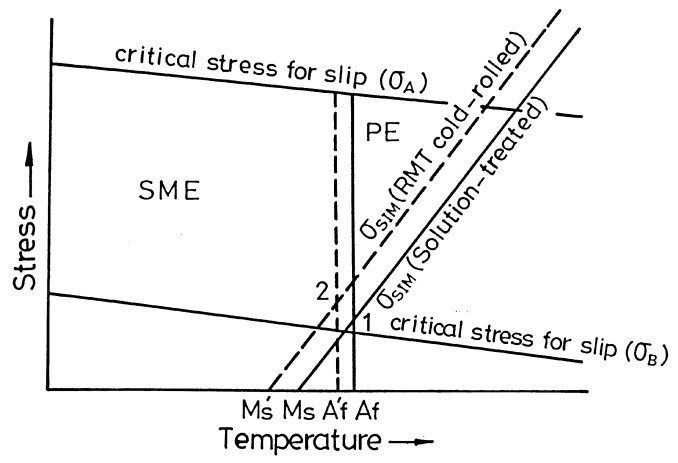

Fig. 11. Schematic diagram representing regions of SME and PE in stress-temperature coordinates for the RMT cold-rolled specimens.

cold-rolled and then RMT processed TiNi SMAs can also significantly increase their stored mechanical energy and improve their energy storage efficiency.

\subsection{Hot-rolling}

Both rolling temperature and thickness reduction have important influences on the work hardening and hardness of hot-rolled plates. The greater the thickness reduction is, the more the retained dislocations, and hence, the higher the rate of work hardening will be, as shown in Fig. 13. At rolling temperatures $\geq 600^{\circ} \mathrm{C}$, recovery or recrystallization occurs.
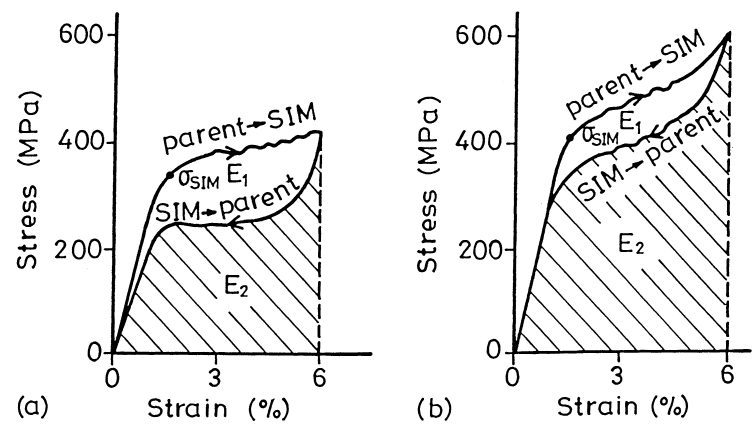

Fig. 12. The tensile stress-strain curves exhibiting the pseudoelasticity characteristics for (a) 10\% thickness-reduced RMT, (b) $20 \%$ thickness-reduced RMT specimens.

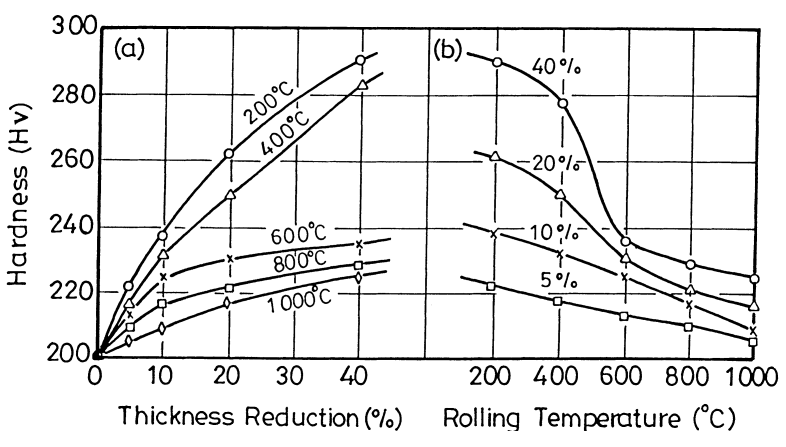

Fig. 13. (a) Hardness $H_{\mathrm{v}}$ vs. thickness reduction, (b) Hardness $H_{\mathrm{v}}$ vs. rolling temperature for the hot-rolled $\mathrm{Ti}_{50} \mathrm{Ni}_{50}$ alloy.

However, because of the short rolling time and the fast cooling rate in air, the recovery or recrystallization is incomplete. The peak temperatures $M^{*}$ and $A^{*}$ of DSC measurement are found to decrease with increasing thickness reduction and with decreasing rolling temperature. This feature is related to the retained dislocations induced by hot-rolling, as can be understood from the inversely linear relationship between peak temperatures and the hardness $H_{\mathrm{v}}$, Fig. 14. Namely, the effect of hot rolling on martensitic transformation temperatures follows the equation [78]:

$\mathrm{Ms}=T_{0}-K \Delta \sigma_{\mathrm{y}}$

Here, the yield stress $\Delta \sigma_{\mathrm{y}}$ of hot-rolled specimen is regarded as being proportional to its hardness.

\subsection{Wire drawing}

Fig. 15 shows drawing stress and specimen hardness versus the degree of cold work for wire drawing tests of $\mathrm{Ti}_{49.7} \mathrm{Ni}_{50.3}$ alloy produced at room temperature. The drawing stress and hardness are found to increase sharply with increasing cold work. This feature reflects the severe work hardening which occurs in TiNi SMAs, necessitating inter-

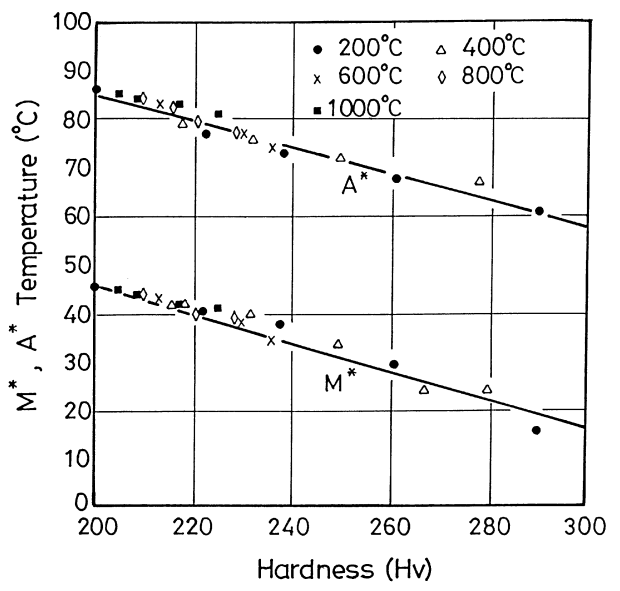

Fig. 14. $M^{*}$ and $A^{*}$ temperatures vs. hardness $H_{\mathrm{v}}$ for the hot-rolled $\mathrm{Ti}_{50} \mathrm{Ni}_{50}$ alloy. 


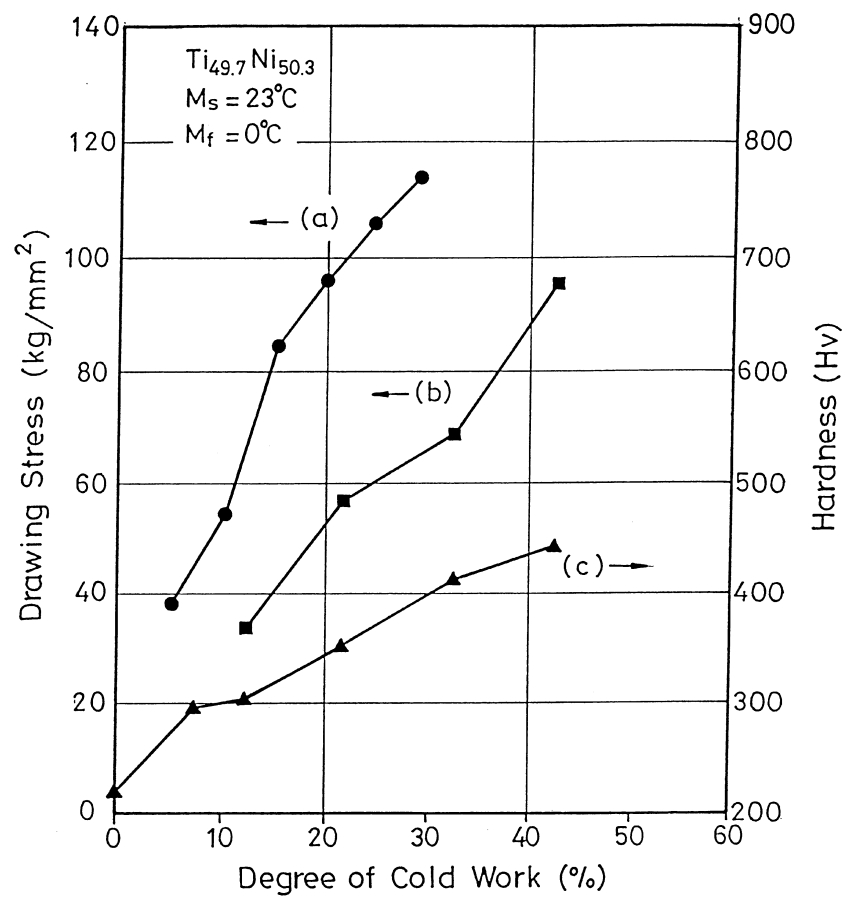

Fig. 15. (a) The drawing stress of single-pass, (b) the drawing stress of multi-pass, (c) specimen's hardness $H_{\mathrm{v}}$ vs. the degree of cold work at room temperature for $\mathrm{Ti}_{49.7} \mathrm{Ni}_{50.3}$ alloy.

annealing during the drawing process. The defects induced by cold drawing depress the martensite transformation but promote the R-phase transformation.

Surface oxide films play an important role in the drawing of TiNi SMAs, especially for extra-fine wires [79,80]. Fig. 16(a-c) shows the SEM observations of $80 \mu \mathrm{m}$ diameter TiNi wires interannaled at $550^{\circ} \mathrm{C}$ for $10 \mathrm{~min}, 550^{\circ} \mathrm{C}$ for $70 \mathrm{~min}$ and $700^{\circ} \mathrm{C}$ for $10 \mathrm{~min}$, respectively. A thin oxide film with a smooth surface can be used as a lubricant during the drawing process. However, a thick oxide film, which has some cracks and spalling on the surface, harms the drawing properties and depresses the SME and PE. Meanwhile, $\mathrm{MoS}_{2}$ is an effective lubricant for the wire drawing of TiNi SMAs. The drawing stress is lower when using $\mathrm{MoS}_{2}$ lubricant than when using other lubricants, and the drawing wire exhibits a quite smooth wire surface after drawing.

\section{Damping characteristics}

Fig. 17 shows the damping ratio $\xi$ and the electrical resistivity versus temperature curves for the $\mathrm{Ti}_{49} \mathrm{Ni}_{51}$ alloy aged at $400^{\circ} \mathrm{C} \times 20 \mathrm{~h}$. In Fig. 17, the damping ratio $\xi$ of B19' martensite has nearly the same magnitude as that of the R-phase but is larger than that of the parent B2 phase. The maximum peaks of the damping ratio $\xi$ appear in the temperature ranges of $\mathrm{B} 2 \leftrightarrow \mathrm{R}$ and $\mathrm{R} \leftrightarrow \mathrm{M}$ transformations.

It is well known that there are abundant twin boundaries in the $\mathrm{B} 19^{\prime}$ martensite and the R-phase of TiNi alloys $[81,82]$. These twin boundaries can be easily moved
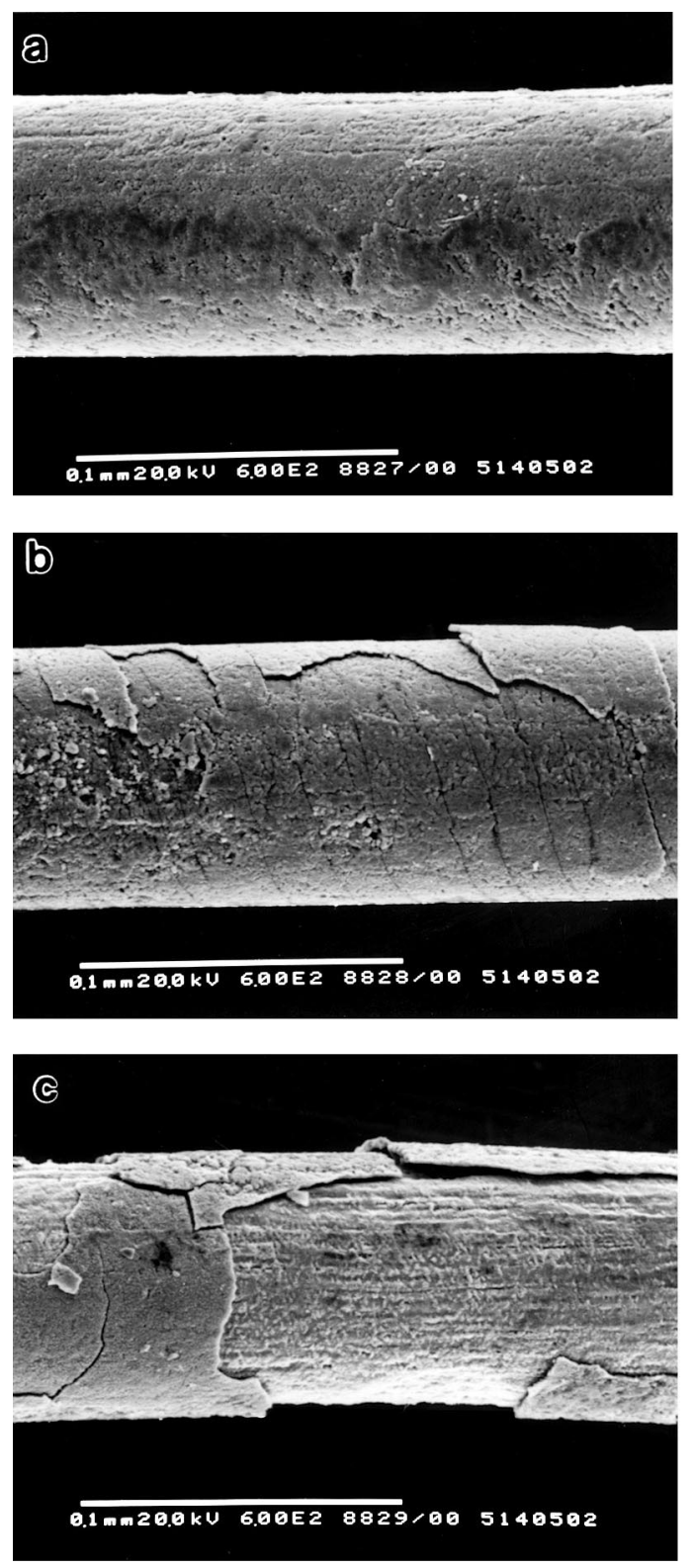

Fig. 16. The SEM observations of $80 \mu \mathrm{m}$ diameter fine TiNi wires for interannealing at (a) $550^{\circ} \mathrm{C} \times 10 \mathrm{~min}$, (b) $550^{\circ} \mathrm{C} \times 70 \mathrm{~min}$ and (c) $700^{\circ} \mathrm{C} \times 10 \mathrm{~min}$.

by the external stress to accommodate the strain. This accommodation/reorientation phenomenon is closely related to the high damping capacity exhibited in TiNi alloys. As shown in Fig. 18, after an elastic response to the stress, an accommodated strain $\varepsilon_{\mathrm{a}}$ in some micro-domains can be produced at the critical stress value, $\sigma_{\mathrm{a}}$. This strain is due to the stress-induced movement of twin boundaries between the variants of martensite or R-phase. The accommodated strain is retained during the unloading but can be reoriented to the opposite direction due to the movement of twin boundaries induced by the following opposite-direction stress, $-\sigma_{\mathrm{a}}$, opening up a relatively large static hysteresis loop, $\Delta W$, for the cyclic movement of twin boundaries. Therefore, the martensite and R-phase of TiNi alloys have a high-damping 


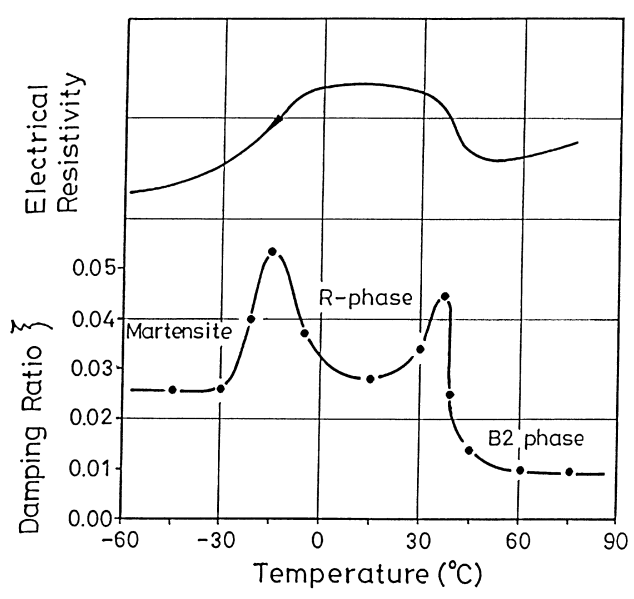

Fig. 17. Damping ratio $\xi$ and electrical resistivity vs. temperature curves for the $400^{\circ} \mathrm{C} \times 20 \mathrm{~h}$ aged $\mathrm{Ti}_{49} \mathrm{Ni}_{51}$ alloy.

capacity, which is comparable to or even higher than cast irons $[83,84]$.

No twin boundaries exist in the parent B2 phase of TiNi alloys, and the dislocation density in the matrix is low [63]. Hence, it is assumed that the damping capacity results from the dynamic hysteresis of lattice defects, such as vacancies or interstitials. Because the dynamic hysteresis loop generally dissipates a smaller quantity of energy, the damping capacity in the B2 phase of TiNi alloys is smaller than that in the martensite or the R-phase.

In the transformation regions of $\mathrm{B} 2 \leftrightarrow \mathrm{M}, \mathrm{B} 2 \leftrightarrow \mathrm{R}, \mathrm{R} \leftrightarrow \mathrm{M}$, there is a maxima of damping capacities attributed to two causes, one arising from the plastic strain and twin-interface movement during the thermal-induced transformation, the other originating from the stress-induced transformation formed by the applied external stress.

As shown in Fig. 19, all the damping capacities of B19/B19' martensite, R-phase and B2 parent phase for the $\mathrm{Ti}_{50} \mathrm{Ni}_{49.5} \mathrm{Fe}_{0.5}$ and $\mathrm{Ti}_{50} \mathrm{Ni}_{40} \mathrm{Cu}_{10}$ ternary alloys are higher than those for the $\mathrm{Ti}_{50} \mathrm{Ni}_{50}$ binary alloy. The lower yielding stress and shear modulus of these ternary alloys are

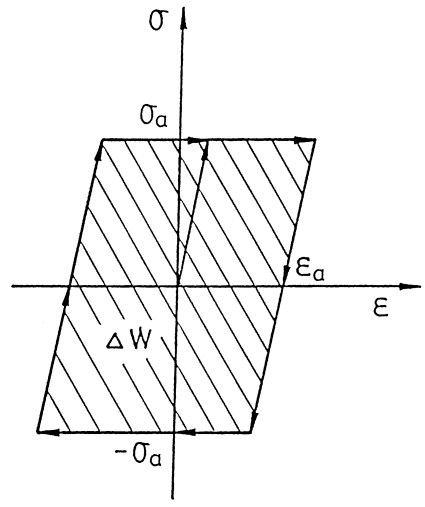

Fig. 18. Schematic stress-strain diagram for the martensite/R-phase accommodation reorientation process $\Delta W$ indicates the energy loss for cycling movement of twin boundaries.
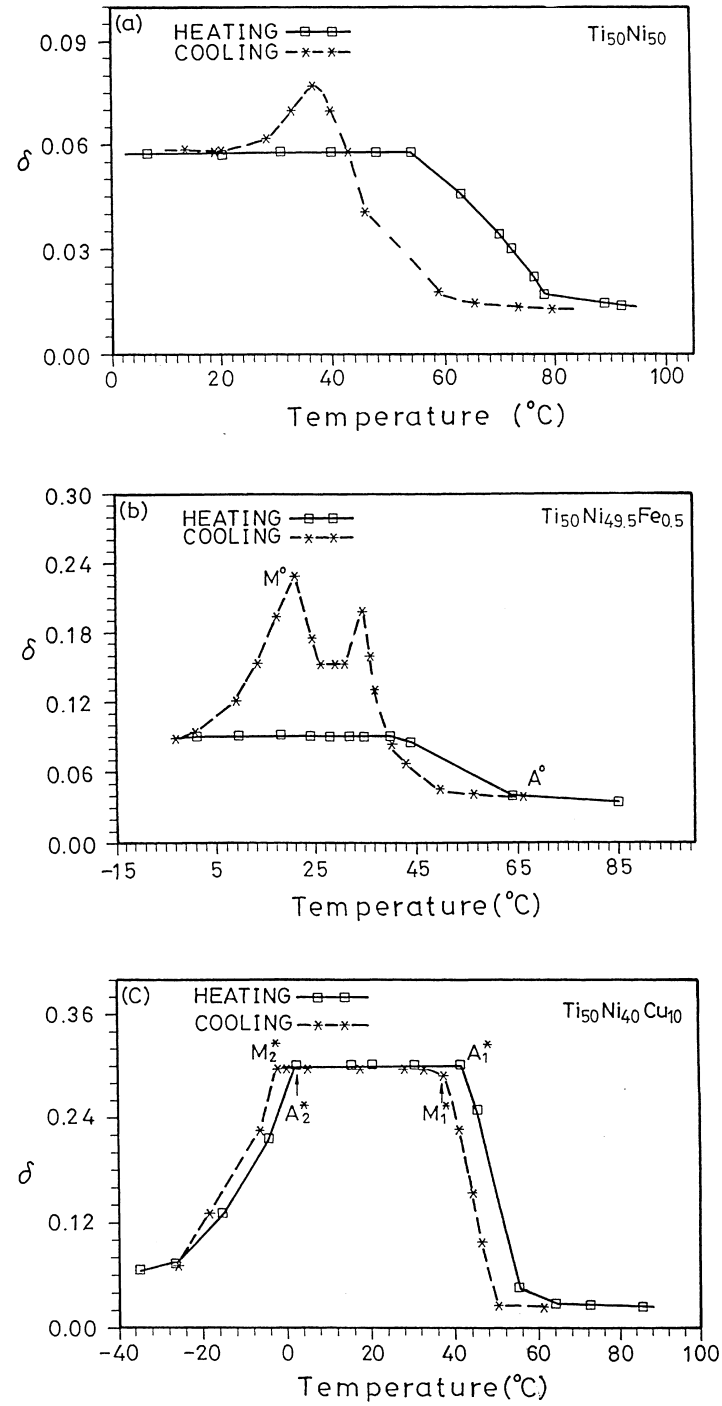

Fig. 19. The damping capacity $\xi$ vs. temperature curves for (a) $\mathrm{Ti}_{50} \mathrm{Ni}_{50}$ alloy, (b) $\mathrm{Ti}_{50} \mathrm{Ni}_{49.5} \mathrm{Fe}_{0.5}$ alloy, and (c) $\mathrm{Ti}_{50} \mathrm{Ni}_{40} \mathrm{Cu}_{10}$ alloy.

assumed to be responsible for their inherent higher damping property. Noticeably, the $\mathrm{Ti}_{50} \mathrm{Ni}_{40} \mathrm{Cu}_{10}$ alloy has an unusually high plateau of damping capacity in the existing region of B19 martensite, assumed to have resulted from the easy movement of twin boundaries of B19 martensite due to its inherently low yielding stress.

\section{TiNi-based high temperature SMAs}

Although TiNi binary alloys are useful as SMAs, they can not be used at temperatures above $\approx 100^{\circ} \mathrm{C}$. Thus, SMAs which can exhibit high temperature SME are in strong demand. The $\mathrm{Ti}-\mathrm{Ni}-\mathrm{X}(\mathrm{X}=\mathrm{Au}, \mathrm{Pd}, \mathrm{Zr})$ alloys are quite promising high temperature SMAs in the temperature range from 150 to $610^{\circ} \mathrm{C}$ [85-90]. Their transformation temperatures can be easily adjusted from low to high by controlling the added amount of $\mathrm{X}$ elements, as shown in 


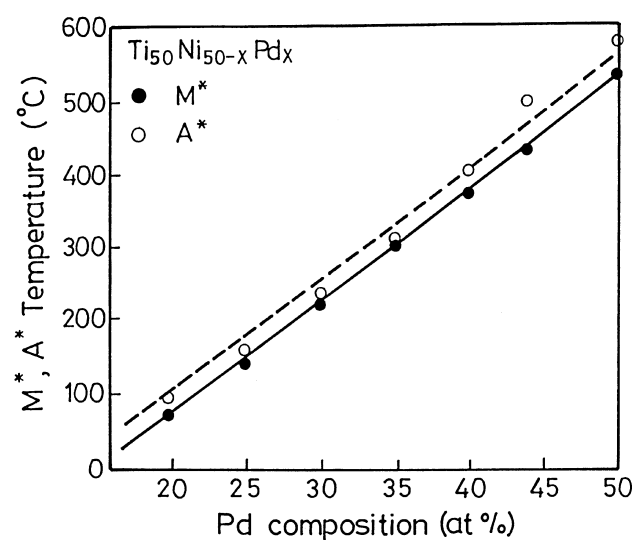

Fig. 20. The $M^{*}$ and $A^{*}$ temperatures vs. Pd composition for the $\mathrm{Ti}_{50} \mathrm{Ni}_{50-x} \mathrm{Pd}_{x}$ alloy.

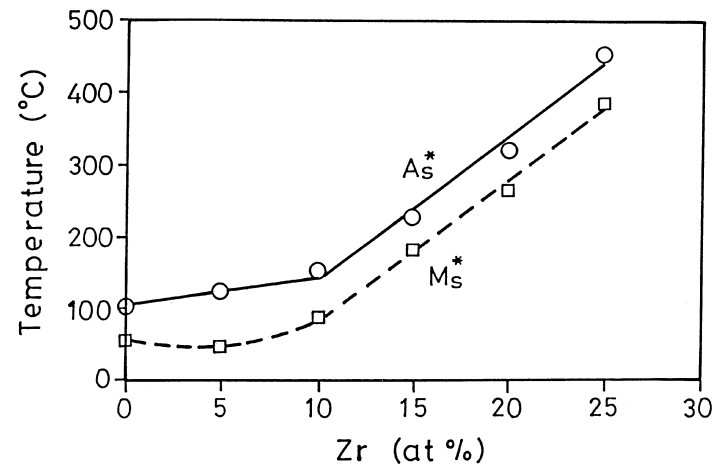

Fig. 21. The transformation temperature of $\mathrm{Ti}_{51.5} \mathrm{Ni}_{48.5} \mathrm{Zr}_{x}$ alloy as a function of $\mathrm{Zr}$ content.

Fig. 20 for the $\mathrm{Ti}_{50} \mathrm{Ni}_{50-x} \mathrm{Pd}_{x}$ alloys and in Fig. 21 for the $\mathrm{Ti}_{51.5-x} \mathrm{Ni}_{48.5} \mathrm{Zr}_{x}$ alloys. Both thermal and mechanically induced martensite stabilization are observed in these Ti-Ni-X alloys [91,92]. The reordering in martensite and the defect pinning on martensite interfaces are considered to be responsible for the martensite stabilization. The characteristics of thermoelastic martensitic transformation are also observed for these alloys, as can be seen from the linear relationship existing between the $\Delta H$ values and the transformation temperatures [93]. Meanwhile, it is worth noting that these high temperature SMAs usually have a one-way SME, but not a two-way SME. This may result from the accumulated 'bias' stresses being easily released when the temperature rises to above Af during the two-way 'training' process [23].

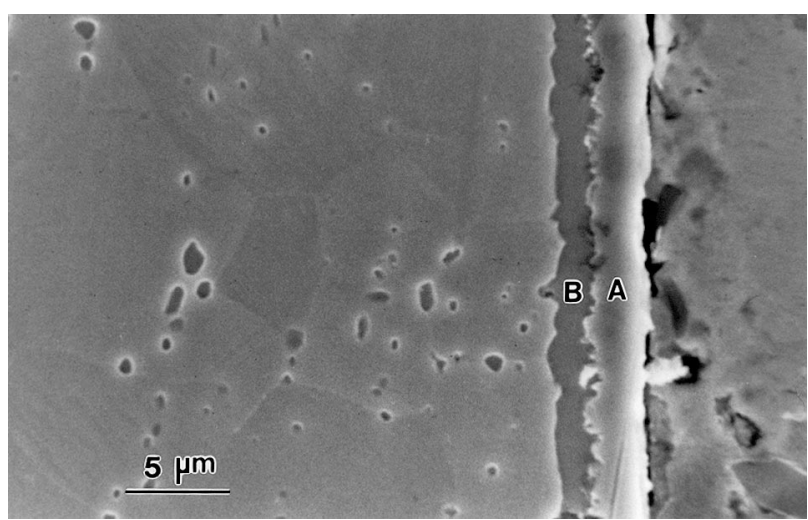

Fig. 22. Scanning electron micrographs of cross-section of equiatomic TiNi alloy after ion nitriding at $900^{\circ} \mathrm{C}$ for $12 \mathrm{~h}$.

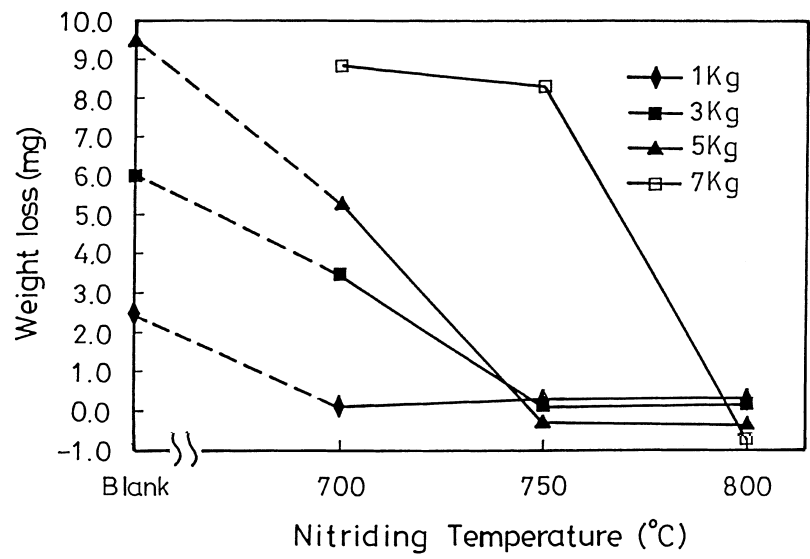

Fig. 23. Weight loss of ion nitrided $\mathrm{Ti}_{50} \mathrm{Ni}_{50}$ specimens after $1-7 \mathrm{~kg}$ load sliding wear, as a function of nitriding temperatures.

\section{Ion nitriding of TiNi SMAs}

Ion nitriding, having a number of advantages over conventional gas nitriding [94,95], is used to improve the surface properties of TiNi SMAs. Fig. 22 shows the cross-section micrograph of typical ion-nitrided $\mathrm{Ti}_{50} \mathrm{Ni}_{50} \mathrm{SMA}$. The outer layer A and inner layer B in Fig. 22 have been identified to be TiN and $\mathrm{Ti}_{2} \mathrm{Ni}$ compounds, respectively, by using XRD and EPMA analysis [38,39]. Table 1 presents the thickness of TiN and $\mathrm{Ti}_{2} \mathrm{Ni}$ layers and the surface hardness of $\mathrm{Ti}_{50} \mathrm{Ni}_{50}$ specimens nitrided at $700-800^{\circ} \mathrm{C}$. In Table 1 , one can easily find that the surface hardness of $\mathrm{Ti}_{50} \mathrm{Ni}_{50}$ specimens can be rapidly raised up by ion nitriding, due to the formation of hard $\mathrm{TiN}$ and $\mathrm{Ti}_{2} \mathrm{Ni}$ compound layers. Fig. 23 shows the

Table 1

Thickness of TiN and $\mathrm{Ti}_{2} \mathrm{Ni}$ compound layers and surface hardness of the $700-800^{\circ} \mathrm{C}$ nitrided $\mathrm{Ti}_{50} \mathrm{Ni}_{50}$ specimens

\begin{tabular}{lllr}
\hline Nitriding temperature $\left({ }^{\circ} \mathrm{C}\right)$ & TiN thickness $(\mu \mathrm{m})$ & $\mathrm{Ti}_{2} \mathrm{Ni}$ thickness $(\mu \mathrm{m})$ & Surface hardness $\left(H_{\mathrm{v}}\right)$ \\
\hline 700 & 0.8 & 0.5 & 854 \\
750 & 1.0 & 1.6 & 1074 \\
800 & 1.5 & 3.6 & 1263 \\
Blank $^{\mathrm{a}}$ & - & - & 203 \\
\hline
\end{tabular}

${ }^{a}$ Blank: before nitriding. 


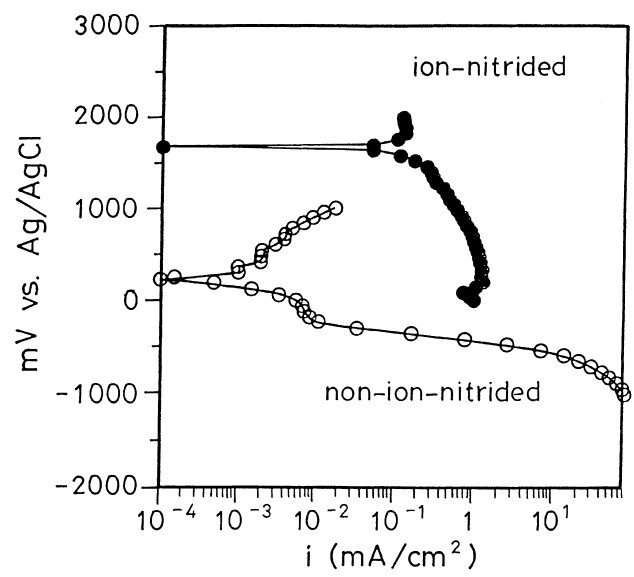

Fig. 24. Anodic potentiodynamic polarization curves for the ion-nitrided and non-ion-nitrided equiatomic TiNi specimens in $0.5 \mathrm{M} \mathrm{HCl}$ solution.

weight loss of ion nitrided $\mathrm{Ti}_{50} \mathrm{Ni}_{50}$ specimens after sliding wear of $1-7 \mathrm{~kg}$ load. As can be seen in Fig. 23, the ion nitrided $\mathrm{Ti}_{50} \mathrm{Ni}_{50}$ specimens, being hardened by the $\mathrm{TiN} / \mathrm{Ti}_{2} \mathrm{Ni}$ compounds, can exhibit a better wear resistance than the blank specimen. Fig. 24 shows the anodic potentiodynamic polarization curves for the ion-nitrided and non-ion-nitrided $\mathrm{Ti}_{50} \mathrm{Ni}_{50}$ specimens in $0.5 \mathrm{M} \mathrm{HCl}$ solution. Values of the corrosion potential $\Phi_{\text {corr }}$ and the corrosion current density $i_{\text {corr }}$ from Tafel extrapolation for $\mathrm{Ti}_{50} \mathrm{Ni}_{50}$ and $\mathrm{Ti}_{50} \mathrm{Ni}_{40} \mathrm{Cu}_{10}$ alloys are listed in Table 2. From Table 2, one can see that the corrosion potential $\Phi_{\text {corr }}$ of ion-nitrided TiNi-based alloys is higher, but the corrosion current density $i_{\text {corr }}$ is lower, than the corresponding values for non-ion-nitrided specimens. This means that the corrosion properties of TiNi SMAs have been improved by ion nitriding [39].

\section{Fabrication and characteristics of TiNi thin films}

Recently, the development of Microelectromechanical System (MEMS) has made TiNi thin films be highly potential candidates for micro-machines due to their large deformation and strong recovery force $[45,54,96,97]$. The $\mathrm{Ti}_{45.6} \mathrm{Ni}_{54.4}$ and $\mathrm{Ti}_{50.4} \mathrm{Ni}_{49.6}$ thin films have been deposited on a 3 in. diameter n-type (1 000$) \mathrm{Si}$-wafer by RF magnetron sputtering. The activation energy of crystallization for the amorphous TiNi thin film is found to be $385 \mathrm{~kJ} / \mathrm{mol}$ using Avrami's method and $374 \mathrm{~kJ} / \mathrm{mol}$ using Kissinger's method [98]. The composition control is very important for the applications of TiNi thin films. The configuration of Ti and Ni targets, and the product of sputtering gas pressure $P$ and target-to-substrate distance $d$, are both important to control the composition of TiNi thin films [53,99]. The sputtered TiNi thin films have interfacial reaction with $\left(\begin{array}{lll}1 & 0 & 0\end{array}\right)$ silicon substrate after annealing above $400^{\circ} \mathrm{C}[100,101]$. $\mathrm{NiSi}_{2}$ binary and $\mathrm{Ti}_{4} \mathrm{Ni}_{4} \mathrm{Si}_{7}, \mathrm{Ti}_{1} \mathrm{Ni}_{1} \mathrm{Si}_{1}$ ternary compounds have been observed around the interface of TiNi thin films and silicon substrate [100].

TiNi thin foils up to $10-\mu \mathrm{m}$ thickness have been successfully fabricated from thin plates with $100-\mu \mathrm{m}$ thickness by using the chemical etching method [102]. To avoid the effects of concentration polarization, ultrasonic agitation is applied to enhance the chemical etching of $\mathrm{HF} / \mathrm{HNO}_{3} / \mathrm{H}_{2} \mathrm{O}$ solution. The higher the $\mathrm{HF} / \mathrm{HNO}_{3}$ volume ratio, the higher the etching rate and the smoother the surface will be. TiNi thin foils can also be fabricated using electric-polishing method, but with a slower etching rate.

\section{Summary remarks}

Developments of TiNi-based SMAs have witnessed a considerable progress in recent years. The two-stage martensitic transformations of $\mathrm{B} 2 \leftrightarrow \mathrm{R}$-phase $\leftrightarrow \mathrm{B} 19^{\prime}$ and $\mathrm{B} 2 \leftrightarrow \mathrm{B} 19 \leftrightarrow \mathrm{B} 19^{\prime}$ have been clarified for both TiNi binary and ternary alloys. The deformation behaviors have been investigated by cold-rolling, hot-rolling and wire drawing. Both SME and PE can be improved by some thermal-mechanical treatments. The damping characteristics of binary and ternary TiNi SMAs have also been systematically studied. Both B19'/B19 martensite and R-phase have high damping capacities due to the stress-induced movement of twin boundaries. The addition of third elements, $\mathrm{Fe}$ and $\mathrm{Cu}$, can largely increase the damping capacity. The $\mathrm{Ti}-\mathrm{Ni}-\mathrm{X}(\mathrm{X}=\mathrm{Au}, \mathrm{Pd}, \mathrm{Zr})$ alloys are quite promising high temperature SMAs in the temperature range from 150 to $610^{\circ} \mathrm{C}$. Their transformation temperatures can be easily adjusted from low to high by controlling the added amount of $\mathrm{X}$ elements. Ion nitriding has also been used to improve the wear and corrosion resistance of TiNi SMAs. The TiNi thin films have been successfully fabricated by using the sputter-deposition technique. The crystallization of the sputtered amorphous TiNi thin films is investigated. The interfacial reactions between TiNi film and Si substrate have also been characterized recently.

Table 2

Corrosion data of the Tafel slope extrapolation calculated from Fig. 24 ( $0.5 \mathrm{M} \mathrm{HCl}$ solution)

\begin{tabular}{lll}
\hline Sample & Corrosion potential, $\Phi_{\text {corr }}(V$ vs. Ag/AgCl $)$ & Corrosion current density, $i_{\text {corr }}\left(\mathrm{mAcm}{ }^{-2}\right)$ \\
\hline $\mathrm{Ti}_{50} \mathrm{Ni}_{50}$ (non-ion-nitrided) & +0.22 & 0.0018 \\
$\mathrm{Ti}_{50} \mathrm{Ni}_{40} \mathrm{Cu}_{10}$ (non-ion-nitrided) & +0.07 & 0.0400 \\
$\mathrm{Ti}_{50} \mathrm{Ni}_{50}($ ion-nitrided) & +1.69 & 0.0011 \\
$\mathrm{Ti}_{50} \mathrm{Ni}_{40} \mathrm{Cu}_{10}$ (ion-nitrided) & +1.70 & 0.0010 \\
\hline
\end{tabular}

${ }^{\text {a }}$ Ion nitrided at $700^{\circ} \mathrm{C}$ for $2 \mathrm{~h}$ and 6 Torr with $\left[\mathrm{N}_{2}\right] /\left[\mathrm{H}_{2}\right]=10$. 
Symbols

B2, R, B19, B19'

cubic, rhombohedral, orthorhombic and monoclinic structures, respectively

$\operatorname{Ms}(\mathrm{Mf}), \operatorname{As}(A f)$ forward and reverse martensitic transformation temperatures, respectively, in the electrical resistivity tests, ${ }^{\circ} \mathrm{C}$

$M^{*}, A^{*}$

forward and reverse martensitic transformation temperatures, respectively, in the DSC measurements, ${ }^{\circ} \mathrm{C}$

$T_{\mathrm{R}}, T_{\mathrm{R}}^{*}$

$P_{\mathrm{C} 1}, P_{\mathrm{H} 1}$

$T_{0}$

$\Delta H$

$\Delta W$

$Q^{-1}$

$\xi$

$\delta$

E

$\sigma$

$\varepsilon$

$\Phi_{\text {corr }}$

$i_{\text {corr }}$

K forward and reverse martensitic transformation temperatures, respectively, in the electrical resistivity tests

and DSC measurements, ${ }^{\circ} \mathrm{C}$

forward and reverse martensitic transformation temperatures, respectively, in the internal friction tests, ${ }^{\circ} \mathrm{C}$

equilibrium temperature, ${ }^{\circ} \mathrm{C}$

heat of transformation, $\mathrm{Jg}^{-1}$

energy loss in a strain cycle

internal friction value, $Q^{-1}=\xi=\delta / \pi$. damping ratio

logarithmic decrement of strain amplitude

mechanical energy

stress, MPa

strain

corrosion potential

corrosion current density

constant

\section{Acknowledgements}

The authors are pleased to acknowledge the financial support for researches on TiNi-based shape memory alloys by the National Science Council of the Republic of China by the Grant NSC87-2216-E002-031.

\section{References}

[1] D.S. Grummon, T.J. Pence, MRS Symp. Proc. 459 (1997) 331.

[2] S. Miyazaki, K. Otsuka, Y. Suzuki, Scripta Metall. 15 (1981) 287.

[3] S. Miyazaki, Y. Ohmin, K. Otsuka, Y. Suzuki, J. de Phys. 43 (1982) C4-255.

[4] S. Miyazaki, T. Imai, Y. Igo, K. Otsuka, Metall. Trans. 17A (1986) 115.

[5] T. Todoroki, H. Tamura, Trans. JIM 28 (1987) 83.

[6] D.N. Abujudom, P.E. Thoma, S. Fariabi, Mater. Sci. Forum 56-58 (1990) 565.

[7] Y. Okamota, H. Hamanaka, F. Miura, H. Tamura, H. Horikawa, Scripta Metall. 22 (1988) 517.

[8] H.C. Lin, S.K. Wu, T.S. Chou, H.P. Kao, Acta Metall. Mater. 39 (1991) 2069.

[9] H.C. Lin, S.K. Wu, Acta Metall. Mater. 42 (1994) 1623.

[10] G. Airoldi, B. Rivolta, C. Turco, Proc. ICOMAT-86, 1986, 69 pp.

[11] T. Tadaki, Y. Nakata, K. Shimizu, Trans. JIM 28 (1987) 883.

[12] K. Iwasaki, R. Hasiguti, Trans. JIM 28 (1987) 363.

[13] M. Nishida, C.M. Wayman, Metallography 21 (1988) 255.

[14] S.K. Wu, H.C. Lin, T.S. Chou, Acta Metall. Mater. 38 (1990) 95.

[15] M. Nishida, T. Honma, Scripta Metall. 18 (1984) 1293.

[16] M. Nishida, C.M. Wayman, Scripta Metall. 18 (1984) 1389.

[17] H.C. Lin, S.K. Wu, Scripta Metall. Mater. 25 (1991) 1295.

[18] C.M. Huang, M. Meichle, M.B. Salamon, C.M. Wayman, Phil. Mag. A47 (1983) 31.

[19] Y.C. Lo, S.K. Wu, H.E. Horng, Acta Metall. Mater. 41 (1993) 747.

[20] E.K. Eckelmeyer, Scripta Metall. 10 (1976) 667.

[21] R. Wasilewski, in: J. Perkin (Ed.), Shape Memory Effects in Alloys, Plenum, New York, NY, 1975, 245 pp.

[22] P.M. Ossi, Mater. Sci. Eng. 77 (1986) L5.

[23] S.K. Wu, C.M. Wayman, Metallography 20 (1987) 359.

[24] K. Enami, T. Yoshida, S. Nenno, Proc. ICOMAT-86, 1987, 103 pp.

[25] K. Enami, E. Horri, J. Takahashi, Iron Steel Inst. Jpn. Int. 29 (1989) 430.

[26] Y.C. Lo, S.K. Wu, C.M. Wayman, Scripta Metall. Mater. 24 (1990) 1571.

[27] C.M. Hwang, C.M. Wayman, Scripta Metall. 17 (1983) 1345, 1449.

[28] H.R. Edmonds, C.M. Hwang, Scripta Metall. 20 (1986) 733.

[29] N.M. Matveeva, Yu.K. Kovneristyi, A.S. Savinov, V.P. Sivokha, V.N. Khachin, J. de Phys. 43 (1982) C4-249.

[30] M. Piao, S. Miyazaki, K. Otsuka, Mater. Trans. JIM 33 (1992) 346.

[31] L.C. Zhao, T.W. Duerig, S. Justi, K.N. Melton, J.L. Proft, W. Yu, C.M. Wayman, Scripta Metall. 24 (1990) 221.

[32] H.C. Lin, S.K. Wu, M.T. Yeh, Metall. Trans. 24A (1993) 2189.

[33] H.C. Lin, S.K. Wu, Y.C. Chang, Metall. Trans. 26A (1995) 851.

[34] P. Clayton, Wear 162-164 (1993) 202.

[35] R.H. Richman, A.S. Rao, D.E. Hodgson, Wear 157 (1992) 401.

[36] R.H. Richman, A.S. Rao, D. Kung, Wear 181-183 (1995) 80.

[37] H.C. Lin, H.M. Liao, J.L. He, K.C. Chen, K.M. Lin, Metall. Mater. Trans. 28A (1997) 1871.

[38] H.C. Lin, H.M. Liao, J.L. He, K.M. Lin, K.C. Chen, Surface Coatings Technol. 92 (1997) 178.

[39] S.K. Wu, C.L. Chu, H.C. Lin, Surface Coatings Technol. 92 (1997) 206.

[40] S.K. Wu, C.Y. Lee, H.C. Lin, Scripta Mater. 37 (1997) 837.

[41] P. Moine, O. Popoola, Scripta Metall. 20 (1986) 305.

[42] K. Endo, R. Sachdeva, Y. Araki, H. Phno, in: A. Pelton, et al. (Ed.), Proc. Shape Memory and Superelastic Tech., Calif. U.S.A., 1994, $233 \mathrm{pp}$.

[43] J.A. Walker, K.J. Gabriel, M. Mehregany, Sensors Actuators A21-23 (1990) 243.

[44] J.D. Busch, M.H. Berkson, A.D. Johnson, MRS Symp. Proc. 230 (1991) 91.

[45] J.D. Busch, A.D. Johnson, C.H. Lee, D.A. Stevenson, J. Appl. Phys. 68 (1990) 6224.

[46] K.R.C. Gisser, J.D. Busch, A.D. Johnson, Arthur B. Ellis, Appl. Phys. Lett. 61 (1992) 1632.

[47] J.S. Madsen, A.P. Jardine, Scripta Metall. 30 (1994) 1189.

[48] J. Zhang, D.S. Grummon, MRS Symp. Proc. 450 (1997) 451.

[49] A. Ishida, A. Takei, S. Miyazaki, Thin Solid Films 228 (1993) 210.

[50] P. Krulevitch, P.B. Ramsey, D.M. Makowiecki, A.P. Lee, M.A. Northrup, G.C. Johnson, Thin Solid Films 274 (1996) 101.

[51] L. Chang, D.S. Grummon, Trans. MRS Jpn. B18 (1994) 1053.

[52] M. Bendahan, P. Canet, J. Seguin, H. Carchano, Mater. Sci. Eng. B34 (1995) 112.

[53] M. Bendahan, P. Canet, J. Seguin, H. Carchano, Thin Solid Films 283 (1996) 61.

[54] E. Quandt, C. Halene, H. Holleck, K. Feit, M. Kohl, P. Schloßmacher, A. Skokan, K.D. Skrobanek, Sensors Actuators A53 (1996) 434. 
[55] S. Miyazaki, S. Kurooka, A. Ishida, M. Nishida, Trans. MRS Jpn. B18 (1994) 1041.

[56] S. Miyazaki, S. Kurooka, T. Hoshiya, Trans. MRS Jpn. B18 (1994) 1045.

[57] K. Nomura, S. Kurooka, A. Takei, Trans. MRS Jpn. B18 (1994) 1049.

[58] S. Miyazaki, A. Ishida, Mater. Trans. JIM 35 (1994) 14.

[59] F. Ciabattari, F. Fuso, E. Airmondo, Appl. Phys. A 64 (1997) 623.

[60] T. Honma, M. Mastumoto, Y. Shugo, M. Nishida, I. Yamazaki, in: H. Kimura, O. Izumi (Ed.), Proc. 4th Int'l Conf. on Titanium, Kyoto, Japan, 1980, 1455 pp.

[61] C.M. Wayman, I. Cornelis, K. Shimizu, Scripta Metall. 6 (1972) 115.

[62] S. Miyazaki, Y. Igo, K. Otsuka, Acta Metall. 34 (1986) 2045.

[63] S. Miyazaki, K. Otsuka, Metall. Trans. 17A (1986) 53.

[64] G.B. Stachowiak, P.G. McCormick, Acta Metall. 36 (1988) 291.

[65] S.K. Wu, H.C. Lin, T.S. Chou, Scripta Metall. 23 (1989) 2043.

[66] S.K. Wu, H.C. Lin, Scripta Metall. Mater. 25 (1991) 1529.

[67] S.K. Wu, C.M. Wayman, Acta Metall. 37 (1989) 2805.

[68] C.Y. Xie, L.C. Zhao, T.C. Lei, Scripta Metall. 23 (1989) 2131.

[69] R. Kainuma, M. Matsumoto, T. Honma, Proc. ICOMAT-86, 1986, 717 pp.

[70] N. Nakanishi, Y. Murakami, S. Kachi, Scripta Metall. 5 (1971) 433.

[71] H. Warlimont, L. Delaey, R.V. Krishnan, H. Tas, J. Mater. Sci. 9 (1974) 1545.

[72] C.M. Hwang, Ph.D Dissertation, Dept. of. Mat. Sci. Eng., University of Illinois, U.S.A., 1981.

[73] E. Goo, R. Sinclair, Acta Metall. 33 (1985) 1717.

[74] H.C. Ling, R. Kaplow, Metall. Trans. 11A (1980) 77.

[75] M.B. Salamon, M.E. Meichle, C.M. Wayman, Phys. Rev. 31B (1985) 7306.

[76] S. Miyazaki, S. Kimura, K. Otsuka, Phil. Mag. 57A (1988) 467.

[77] H.C. Lin, S.K. Wu, Scripta Metall. Mater. 26 (1992) 59.

[78] H.C. Lin, S.K. Wu, Mater. Sci. Eng. A158 (1992) 87.

[79] C.M. Jackson, H.J. Wagner, R.J. Wasilewski, NASA-SP5110, 1972, $19 \mathrm{pp}$.

[80] M. Aiba, H. Nagai, M. Asakawa, Materia Jpn. JIM 31 (1992) 541.
[81] T. Saburi, S. Nenno, Proc. Int. Conf. on Solid to Solid Phase Transf., ASM, Metals Park, OH, 1982, 1455 pp.

[82] S. Miyazaki, C.M. Wayman, Acta Metall. 36 (1988) 181.

[83] J.S. Zhu, R. Schaller, W. Benoit, Phys. Status Solidi A 108 (1988) 61.

[84] K.N. Melton, O. Mercier, Acta Metall. 29 (1980) 393.

[85] N.M. Matreeva Kovneristyi, A.S. Savinov, V.P. Sivokha, V.N. Kharchin, J. de Phys. 43 (1982) C4-249.

[86] H.C. Donkerslost, J.H.N. Van Vucht, J. Less Common Metals 20 (1970) 83.

[87] H.C. Yi, J.J. Moore, Mater. Sci. Forum 56-58 (1990) 735.

[88] J.H. Mulder, J.H. Mass, J. Beyer, in: C.M. Wayman, J. Parkins (Ed.), Proc. ICOMAT-92, Calif. U.S.A., 1992, 869 pp.

[89] D. Golberg, Y. Xu, Y. Murakami, S. Morito, K. Otsuka, T. Ueki, H. Horikawa, Scripta Metal. Mater. 30 (1994) 1349.

[90] Y.S. Li, Y.B. Jin, R.H. Yu, Acta Metall. Sinica 26 (1990) 113.

[91] S.K. Wu, Y.C. Lo, Mater. Sci. Forum 56-58 (1990) 619.

[92] Y.C. Lo, S.K. Wu, Trans. MRS Jpn. 18B (1994) 1029.

[93] S.K. Wu, H.C. Lin, in: H. Chen, et al. (Eds.), Proc. of Displacive Phase Trans. and Their Applications in Mater., Illinois, U.S.A., 1998, $197 \mathrm{pp}$.

[94] ASM Handbook, Vol. 4, 9th Edition, ASM, Metals Park, OH, U.S.A., 1991, $387 \mathrm{pp}$.

[95] W. Kovaces, W. Russel, Proc. of the ASM Int'l Conf. on Ion Nitriding, ASM, Metals Park, OH, U.S.A., 1986, 9 pp.

[96] R.H. Welf, A.H. Heuer, J. Microelectromech. Syst. 4 (1995) 206.

[97] P. Krulevitch, A.P. Lee, P.B. Ramsey, J.C. Trevini, J. Hamilton, M.A. Northrup, J. Microelectromech. Syst. 5 (1996) 270.

[98] J.Z. Chen, S.K. Wu, Thin Solid Films 339 (1999) 194.

[99] J.Z. Chen, Master Thesis, Institute of Materials Sci., Eng., National Taiwan University, Taipei, TAIWAN, 1998.

[100] S.K. Wu, J.Y. Wang, Y.J. Wu, M.N. Yu, F.R. Chen, J.J. Kai, submitted to Thin Solid Films, 1999.

[101] S. Stemmer, G. Duscher, C. Scheu, H. Heuer, M. Ruhle, J. Mater. Res. 27 (1997) 1734.

[102] J.Z. Chen, S.K. Wu, Mater. Chem. Phys. 58 (1999) 162. 